\title{
Distribution of Iron Sand in the Widarapayung Coast Area at Regency of Cilacap Based on Magnetic Anomaly Data
}

\author{
Sehah*, Sukmaji Anom Raharjo, dan Muhammad Andi Kurniawan \\ Study Program of Physics, Faculty of Mathematic and Natural Science \\ Jenderal Soedirman University \\ Dr. Suparno no.61 Karangwangkal, Purwokerto \\ "E-mail : sehah.geophysics@gmail.com
}

DOI: http://dx.doi.org/10.13057/ijap.v6i02.1896

\begin{abstract}
Interpretation on the magnetic anomalies data has been done in the Widarapayung coast area, District of Binangun, Regency of Cilacap to identify distribution of iron sand. The acquisition of magnetic intensity data in this area has been done in December 2015 and May 2016 using Proton Precession Magnetometer (PPM) with type of GSM-19T. The research area extends on the geographic positions of $109.2501^{\circ} \mathrm{BT}-109.2702^{\circ} \mathrm{E}$ and $7.6781^{\circ} \mathrm{LS}-7.6986^{\circ} \mathrm{S}$. Magnetic anomalies data modeling is done with using Mag2DC for Windows software so obtained some subsurface anomalous objects model. The anomaly object model having a value of magnetic susceptibility of $0.0093 \mathrm{cgs}$ unit is interpreted as iron sand interspersed with silt, clay, sand, and gravel from the alluvium formation. This formation is lain at a depth of 1.709 to $11.966 \mathrm{~m}$ and a length of $1576.7 \mathrm{~m}$. The iron sand contained in this formation is estimated prospects for exploitation. Based on the interpretation results, alluvium formation is also found at a depth of 1.140 to $30.769 \mathrm{~m}$, which expected be composed of silt, clay, sand, and gravel with a magnetic susceptibility value of $0.0051 \mathrm{cgs}$ unit. The content of iron sand in this $2^{\text {nd }}$ alluvium formation is expected to be relatively small.
\end{abstract}

Keywords: distribution of iron sand, magnetic anomalies data, Widarapayung Coast

ABSTRAK

Interpretasi terhadap data anomali magnetik telah dilakukan di kawasan Pantai Widarapayung Kecamatan Binangun Kabupaten Cilacap untuk mengidentifikasi sebaran pasir besi. Akuisisi data intensitas magnetik dalam penelitian telah dilakukan pada bulan Desember 2015 dan Mei 2016 menggunakan Proton Precession Magnetometer (PPM) tipe GSM-19T. Daerah penelitian membentang pada posisi geografis $109,250^{\circ} \mathrm{BT}-109,2702^{\circ} \mathrm{BT}$ dan $7,6781^{\circ} \mathrm{LS}-$ $7,6986^{\circ} \mathrm{LS}$. Pemodelan data anomali magnetik telah dilakukan menggunakan perangkat lunak Mag2dc for Windows sehingga diperoleh beberapa model benda anomali bawah permukaan. Model benda anomali dengan nilai suseptibilitas magnetik 0,0093 satuan cgs diinterpretasi sebagai pasir besi yang berselingan dengan lanau, lempung, pasir, dan kerikil dari formasi alluvium. Formasi ini terletak pada kedalaman 1,709-11,966m dan panjang $1.576,7 \mathrm{~m}$. Pasir besi yang terdapat pada formasi ini diperkirakan prospek untuk dieksploitasi. Berdasarkan hasil interpretasi, formasi alluvium juga ditemukan pada kedalaman $1,140-30,769 \mathrm{~m}$, yang diperkirakan tersusun atas lanau, lempung, pasir, dan kerikil dengan nilai suseptibilitas magnetik sebesar 0,0051 satuan cgs. Kandungan pasir besi di dalam formasi alluvium yang kedua ini diperkirakan relatif kecil.

Kata Kunci: sebaran pasir besi, data anomali magnetik, Pantai Widarapayung 


\section{INTRODUCTION}

The southern coast of Cilacap has a potency of iron ore mines material having extremely economical value. The mining activity in this region has produced approximately 300,000 tons of iron ore concentrate per years. The iron is an essential raw material used by almost all industries for centuries. Currently ferrous metals is used as basic ingredient of concrete construction of buildings, bridges, means of transport such as trains, cars, motorcycles, and others. In additions as raw material for the steel industry, the iron (in the form of iron sand) can also be used as mixture of cement, basic ingredient of dry ink on the photocopy machines (toner), laser printers, dye in the paint, and battery ${ }^{[1,2]}$.

The main requirement of presence of the iron sand is volcanic eruption activity or magma intrusion and the river running through the beach. Volcano is source of iron sand coloring of black. Location of volcanoes along the Java Island that closer to southern, as well as many rivers flow towards western and southern, so be resulted iron sand from the eruption of active volcanoes and magma intrusion transported towards the beach and accumulated on the beach. Sources of iron sand are rocks that are intermediate to base and andesitic to basaltic [3].

One of coast in Regency of Cilacap which estimated to contain iron ore prospectly is the Widarapayung Coast that located about $35 \mathrm{~km}$ from the eastern Cilacap City. The iron ore reserve in this coast including the "not yet mined" with an area of about 500 hectares with MD $12.20 \%$ and content of $\mathrm{Fe}$ above $53 \%$. The iron ore reserve is spreading from village of Welahan Wetan District of Binangun to village of Jetis District of Nusawungu, with estimated mass of about 744,678.85 tons ${ }^{[4]}$. Especially, the black iron sand is generally dominated by minerals that composed of magnetite $\left(\mathrm{Fe}_{3} \mathrm{O}_{4}\right)$, hematite $\left(\mathrm{Fe}_{2} \mathrm{O}_{3}\right)$, limonite $\left(\mathrm{Fe}_{2} \mathrm{O}_{3} \cdot \mathrm{nH}_{2} \mathrm{O}\right)$ and siderite $\left(\mathrm{FeCO}_{3}\right)$. The increasingly black color of the iron sand shows that the concentration of elements of $\mathrm{Fe}$ is also increasingly high ${ }^{[3]}$.

Every rock or magnetic minerals under the earth's surface, such as iron ore and other rocks can be assumed as a magnetic anomaly. Magnetic anomaly is a magnetic field originating from the geological structures or the distributions of magnetized minerals and rocks in the subsurface of the earth. According to Telford et.al. ${ }^{[5]}$, a volume consisting of magnetic materials can be considered as a magnetic dipole as shown in Figure 1. The magnetization occuring in materials depends on the quantity of magnetic induction received from the earth main magnetic field.

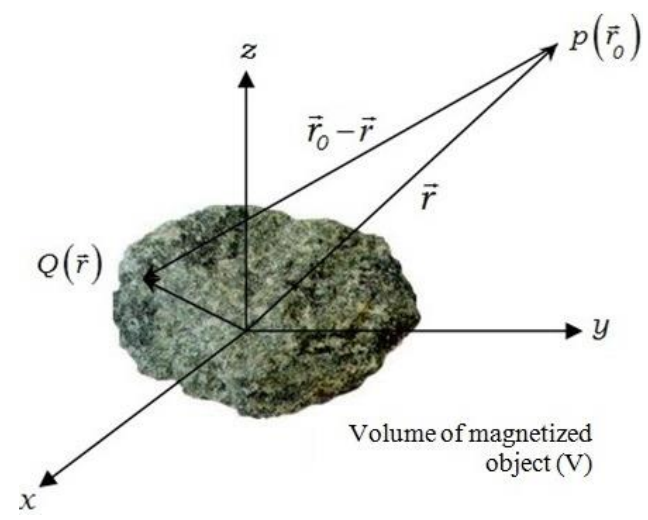

Figure 1. (Colour Online) Magnetic anomaly from the rock or anomalous object in the subsurface of the earth ${ }^{[5]}$. 
Based on Figure 1, the value of the magnetic potential in the entire volume of the object can be formulated as ${ }^{[5]}$ :

$$
V\left(\vec{r}_{O}\right)=-C_{m} M \frac{\partial}{\partial \alpha} \int\left[\frac{d V}{\left|\vec{r}_{O}-\vec{r}\right|}\right]
$$

where $M$ is the magnetic dipole moment per volume unit and $C_{\mathrm{m}}$ is a constant. The value of the total magnetic induction of these rocks can be formulated by ${ }^{[5]}$ :

$$
\vec{B}\left(\vec{r}_{O}\right)=C_{m} \nabla \int_{V} \vec{M}(\vec{r}) \bullet \nabla\left[\frac{1}{\left|\vec{r}_{O}-\vec{r}\right|}\right] d V
$$

The magnetic induction field as equation (2) is referred to as magnetic anomaly that mixed by main magnetic field of earth $B_{0}$ at every measurement point locations. Thus, the total magnetic field actually measured in the equipment at each location of the Earth's surface is combination of the main magnetic field of the earth $\left(B_{0}\right)$ and the anomaly magnetic field $\left(B_{\mathrm{r} 0}\right)$ with assume that the external magnetic field value is ignored. But if the external magnetic field is not ignored, the value of the measured magnetic anomaly at each location of the Earth's surface can be expressed by ${ }^{[6]}$ :

$$
B_{\mathrm{r} 0}=B_{\mathrm{T}}-B_{0}-B_{\mathrm{H}}
$$

Generally the magnetic anomaly $\left(B_{\mathrm{r} 0}\right)$ is data as target in the research. The anomaly value is derived from variations in the magnetization of minerals and rocks in the subsurface of the earth which used as a basis for modeling and interpretation of the geological structure or the subsurface rocks ${ }^{[7]}$.

\section{RESEARCH METHODS}

\section{Time and Location}

This research has been done in December 2015 and May 2016. The data acquisition has been done in Widarapayung Coast area, District of Binangun, Regency of Cilacap. The data processing, modeling, and interpretation have been carried out in the Laboratory of Electronics, Instrumentation, and Geophysics, Faculty of Mathematic and Natural Science (MIPA), Jenderal Soedirman University Purwokerto. 


\section{Materials and Equipment}

Materials and equipment required in this research completely can be seen in Table 1.

Table 1. Material and equipment used in the research

\begin{tabular}{cll}
\hline No. & \multicolumn{1}{c}{ Nama Peralatan } & Jumlah \\
\hline 1 & Proton Precession Magnetometers with type of GSM-19T, product of GEM System, & 1 set \\
2 & and sensitivity of 0.05 nT & 1 piece \\
3 & Global Positioning System (GPS) from Garmin & 1 copies \\
4 & Geologic Map of Banyumas-Cilacap Sheets & 1 copies \\
5 & Topographic Map of Widarapayung Coast & 1 piece \\
6 & Compass & 1 set \\
7 & Laptop and printer & 1 package \\
8 & Surfer Software version 10.0 & 1 package \\
9 & Program of Watfor 77 & 1 package \\
10 & Mag2DC for Windows Software version 1.59 & 1 package \\
\hline
\end{tabular}

\section{Research Procedure}

Stages of the activities carried out in this research include of data acquisition in the field, data processing, anomaly data modeling, and final interpretation. Data obtained from the acquisition in the field is the total magnetic intensity, geographical position of measuring points, time, and environmental condition. The next processing step is the correction to the total magnetic intensity data $\left(B_{\mathrm{T}}\right)$, which includes the daily correction $\left(\Delta B_{\text {harian }}\right)$ and the correction of the main magnetic field of the earth $\left(B_{0}\right)$ in order to obtain the total magnetic anomalies data $(\Delta B)$ that can be expressed by equation ${ }^{[6]}$ :

$$
\Delta B=B_{T} \pm \Delta B_{\text {Harian }}-B_{0}
$$

The total magnetic anomalies data obtained from the equation (4) is distributed over the topographic surface, so that needs to be transformed into a horizontal surface. The process of transformation of anomalies data into a horizontal surface can be made using the Taylor Series Approximation by equation ${ }^{[8]}$ :

$$
\Delta B\left(\lambda, \vartheta, h_{0}\right)^{[i+1]}=\Delta B(\lambda, \vartheta, h)-\sum_{n=0}^{\infty} \frac{\left(h-h_{0}\right)^{n}}{n !} \frac{\partial^{n}}{\partial z^{n}} \Delta B\left(\lambda, \vartheta, h_{0}\right)^{[i]}
$$

The equation (5) is expressed in the iteration, where $\Delta B\left(\lambda, \vartheta, h_{0}\right)$ which is an anomaly data distributed on a plat surface can be estimated through approach, i.e. a value of $\Delta B\left(\lambda, \vartheta, h_{0}\right)$ obtained from first iteration can be used to estimate a value of $\Delta B\left(\lambda, \vartheta, h_{0}\right)$ in next iteration or to $(\mathrm{i}+1)$. The iteration process is done in the average topographic surface high, so that the value of $\Delta B\left(\lambda, \vartheta, h_{0}\right)$ obtained have shown convergent ${ }^{[8]}$.

The magnetic anomalies data obtained from the equation (5) must be corrected by regional magnetic effects, because the target of this research is the subsurface rocks near surface, as the iron sand ${ }^{[8]}$. The regional magnetic anomalies data can be obtained through process of upward continuation of the magnetic anomalies data been distributed on a horizontal surface to a certain height, such that the anomalies data interval of one point to other point in a round have shown very fine trend ${ }^{[9]}$. The equation of the upward continuation of the anomalies data using the second Green identity, namely ${ }^{[8]}$ : 


$$
\Delta B\left(\lambda^{\prime}, \vartheta^{\prime}, h_{0}+\Delta h\right)=\frac{\Delta h}{2 \pi} \int_{-\infty}^{\infty} \int_{-\infty}^{\infty} \frac{\Delta B\left(\lambda, \vartheta, h_{0}\right)}{\sqrt{\left(\left(\lambda^{\prime}-\lambda\right)^{2}+\left(\vartheta^{\prime}-\vartheta\right)^{2}+\Delta h^{2}\right)^{3 / 2}}} d \lambda d \vartheta
$$

The regional magnetic anomalies data obtained from equation (7) must be corrected to the magnetic anomalies data been distributed on a horizontal surface, so that obtained the local magnetic anomalies data by the equation ${ }^{[10]}$ :

$$
\Delta B_{\text {Lokal }}=\Delta B\left(\lambda, \vartheta, h_{0}\right)-\Delta B\left(\lambda^{\prime}, \vartheta^{\prime}, h_{0}+\Delta h\right)
$$

Based on the local geological information, therefore the modeling of the local magnetic anomalies data is done using Mag2DC for Windows software version of 1.59 to obtain some subsurface anomalous objects model. The interpretation on the obtained anomalous objects model is done to determine the distribution of iron sand and the other subsurface rocks formation in the research area.

\section{RESULTS AND DISCUSSION}

\section{Magnetic Field Data Processing Results}

Data acquisition of the total magnetic intensity has been carried out at 134 locations points extends on the geographic position of $109.2501^{\circ}-109.2702^{\circ} \mathrm{E}$ and $7.6781^{\circ}-7.6986^{\circ} \mathrm{S}$. The data acquisition was done using Proton Precession Magnetometer (PPM) with type of GSM $-19 \mathrm{~T}$ and sensitivity of $0,05 \mathrm{nT}$. The result is the total magnetic field intensities data at each location with value ranging of $44332.06-45586.37 \mathrm{nT}$. To obtain the value of the total magnetic anomaly, then the total magnetic field intensities data is corrected by the daily correction and IGRF correction. The daily correction aims to eliminate the variations of the earth extraterrestrial magnetic field and the corrections IGRF aim to reduce the main magnetic field value of the earth. Based on the online calculations ${ }^{[11]}$, the IGRF value of this research area is 44962.0nT. After the daily correction and IGRF correction, then be obtained the total magnetic anomalies data with value ranging of $-685.58-578.78 \mathrm{nT}$. The total magnetic anomalies contour map is shown in Figure 2 (a)

The total magnetic anomalies data that been obtained is distributed over the topographic surface of the research area. In order mathematically, the magnetic anomalies data can not be processed next stage if the data is not distributed on a horizontal surface. The method that used to transform the anomalies data from the topographic surface to the horizontal surface is the Taylor series approximation ${ }^{[8]}$. The horizontal surface that selected is at an average elevation of topography i.e. $19.82 \mathrm{~m}$ above reference spheroid point in order the iteration process reach a convergent quickly ${ }^{[8]}$. The magnetic anomalies contour map that been distributed on a horizontal surface is shown in Figure 2 (b). Based on these maps, we can be known that the magnetic anomalies data been reduced in horizontal surface is more convergent than the anomalies data that still in the topographic surface. 


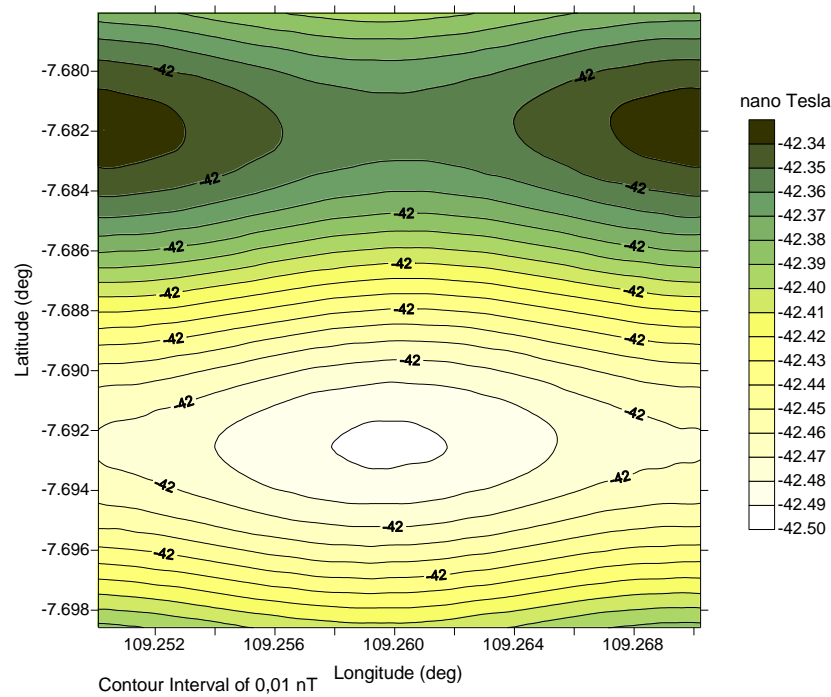

Figure 3. (Colour Online) The regional magnetic anomalies contour map of the research area that obtained from upward continuation process at a height of $2,750 \mathrm{~m}$ above reference spheroid.

The local magnetic anomaly data is obtained by subtracting of the total magnetic anomaly data by the regional magnetic anomaly data ${ }^{[10]}$. The local magnetic anomalies data is located at the same height as the total magnetic anomalies data distributed on a horizontal surface i.e. $19.82 \mathrm{~m}$ which is the topographic average elevation of the research area as shown in Figure 4. Based on the contour map, be known that the magnetic anomalies trend in the research area is relatively balanced between high anomalous that concentrated in the north and low anomalous that concentrated in the south. The result obtained is very logic because in the northern zone is found the iron ore in the surface or subsurface of the earth. The magnetic susceptibility value of the iron ore is relatively high so it has contributing greatly to the measured magnetic anomalies values on the surface. While in the southern of the research area is dominated by the coast sand (sediment rocks), with the magnetic susceptibility value is relatively low so that the magnetic anomaly value is also low ${ }^{[12]}$.

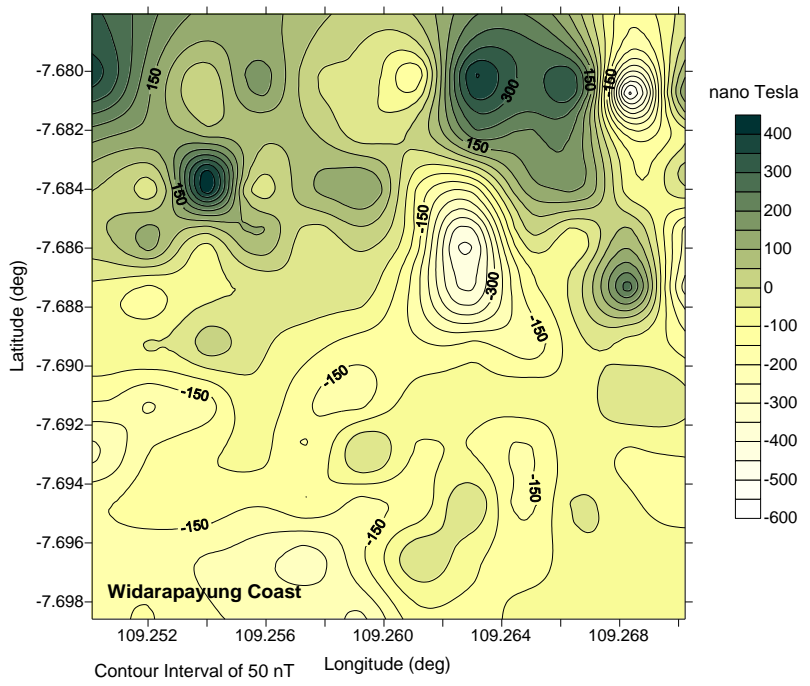

Figure 4. (Colour Online) The local magnetic anomalies contour map of the research area.

The modelling of the subsurface magnetic anomalous objects is done using Mag2DC for Windows software version 1.59. The modelling is done by creating a path (line section) on 
a contour map from the positive anomalous zone leading to the negative anomalous zone that estimated as the target of research, namely the distribution of iron sand. The modeling trajectory that has been made on the local magnetic anomaly contour map can be seen in Figure 5. The modeling is done on the local magnetic anomalies data, where the anomalies data is extracted from the modeling trajectory using Surfer software version 10.

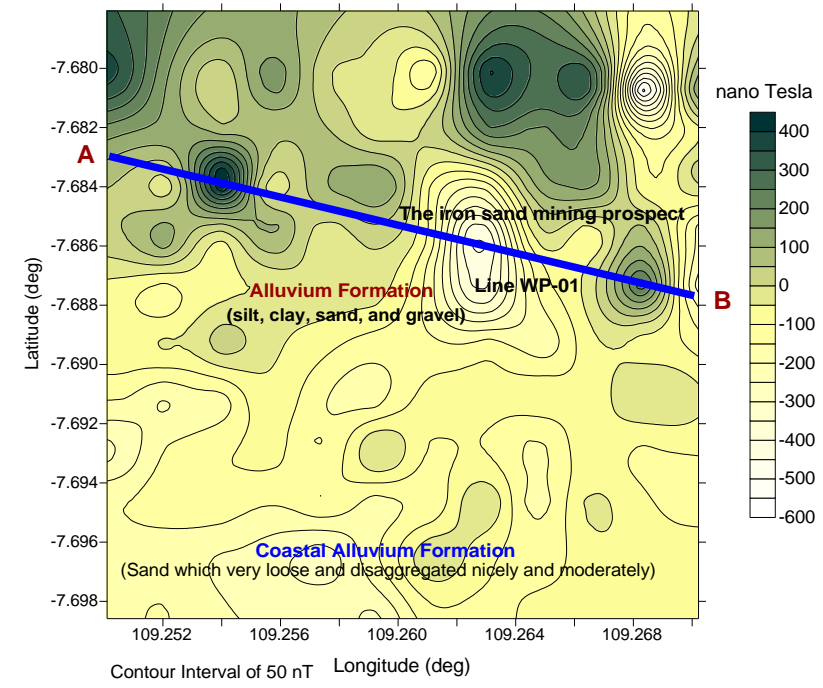

Figure 5. (Colour Online) The modelling trajectories of $\mathrm{AB}$ on the local magnetic anomaly contour map.

\section{Modelling Results and Interpretation}

In the modeling of the magnetic anomaly, needed some earth's magnetic field parameter of the research area that includes IGRF value of $45015.5 \mathrm{nT}$, declination angle of $0.8733^{\circ}$, inclination angle of $-32.534^{\circ}$ and a strike length of $100 \mathrm{~m}^{[11]}$. The modelling is done on the magnetic anomaly data along the trajectory of $\mathrm{AB}$ directed straight from point of $\mathrm{A}$ on the position of $109.25217^{\circ} \mathrm{E}$ and $7.68353^{\circ} \mathrm{S}$ to point of $\mathrm{B}$ on the position of $109.26991^{\circ} \mathrm{E}$ and $7.68796^{\circ} \mathrm{S}$. The magnetic anomalies data is extracted along the trajectory of $\mathrm{AB}$ with a length of $2036.51 \mathrm{~m}$. The amount of the anomalies data that extracted and modeled is 44 pieces with a distance of $47.35 \mathrm{~m}$ among one point to another point. The angle of trajectory is $104.033^{\circ}$ relatively from north to east.

The modeling was done using Mag2DC for Windows software with matching between the model anomalies data to observations anomalies data. After having achieved a matching between two data or curves, then obtained seven subsurface anomalous objects assumed as some subsurface rocks in the research area as shown in Figure 6. While the interpretation results of the types and the formations of rocks completely with magnetic susceptibility contrast value $(\Delta \chi)$ and estimated magnetic susceptibility value $(\chi)$ can be seen in Table 2 . For modeling of magnetic anomalous objects, the value of average magnetic susceptibility of subsurface rocks is estimated about $0.0080 \mathrm{cgs}$ unit based on the geological information of average rocks in the research area. The estimated magnetic susceptibility value of each rock is obtained by adding the average rocks magnetic susceptibility value to the magnetic suseptiblity contrast value of each rock.

Based on the geological information, the rock formation in this research area is composed by the alluvium formation consisting of silt, clay, sand, and gravel containing of iron ore; the coastal alluvium consisting of sand which very loose and disaggregated nicely and 
moderately; and the Halang formation consisting of interspersed of sandstone, claystone, marl, and tuff with inserts breccia ${ }^{[12]}$. The alluvium formation is located in the northern of the research area and the coastal alluvium is located in the southern. While the Halang formation is estimated lie below the two rocks formation ${ }^{[12]}$. In the eastern of the research area appears of the Karangbolong Mountains is found the Gabon formation containing of andesite breccia, tuff, coarse sandstone, lapilli, lava, and modified lava and sediment. This formation is estimated lie in the bottom of all the rocks formations in the research area and found many intrusion of andesite rocks, which possible becomes one of the sources of the iron sand in the research area ${ }^{[12]}$

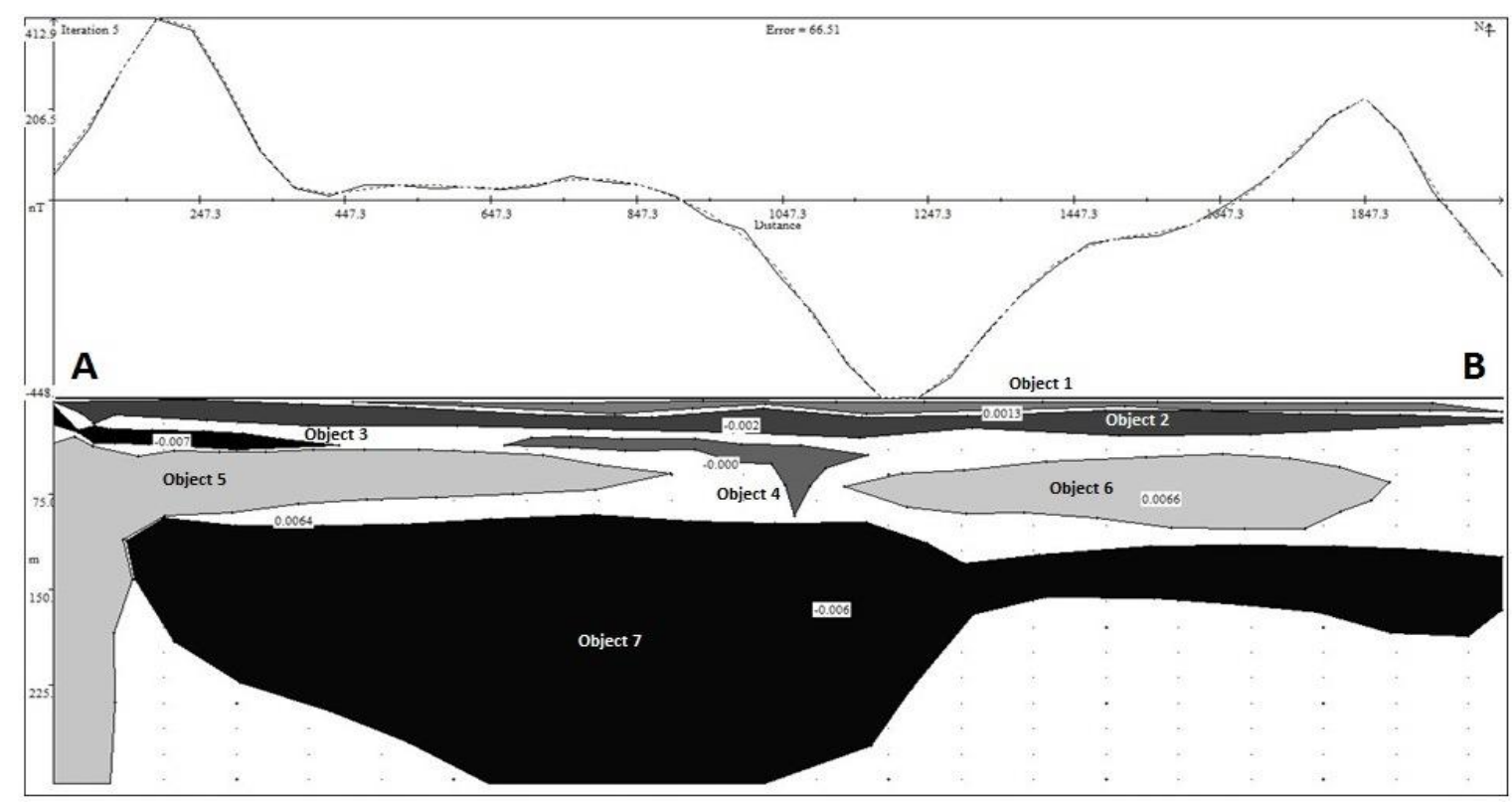

Figure 6. The result of modeling to the magnetic anomalies data using Mag2DC for Windows software on the trajectory of $\mathrm{AB}$ (equipped with a magnetic susceptibility contrast value of each object models).

Based on the interpretation results of the subsurface anomalous objects model, so obtained a deposit of the iron sand interspersed with silt, clay, sand, and gravel including alluvium formation at a depth of 1.709 to $11.966 \mathrm{~m}$ and a length of $1576.699 \mathrm{~m}$. This rocks magnetic susceptibility value is estimated equal to $0.0093 \mathrm{cgs}$. The iron sand found in this formation is thought to be the part that not been mined and estimated very prospects for exploitation economically. In addition, the iron sand is also expected be found in the rocks deposit that lie below it composed of silt, clay, sand, and gravel from the alluvium formation at a depth of $1.140-30.769 \mathrm{~m}$, a length of $1987.116 \mathrm{~m}$, and a magnetic susceptibility of $0.0051 \mathrm{cgs}$ unit. However, the iron sand content in the second alluvium formation are expected small based on the magnetic susceptibility value and the geological information of the research area, so that to be less prospect of being exploited ${ }^{[12]}$. 
Table 2. The modeling results of the magnetic anomalies data on the trajectory of $\mathrm{AB}$ and its interpretation based on the magnetic susceptibility value in cgs unit

\begin{tabular}{|c|c|c|c|c|}
\hline No. & $\begin{array}{l}\text { Anomalous Object and } \\
\text { its Depth (meter) }\end{array}$ & $\begin{array}{c}\Delta \chi \\
\text { (cgs units) }\end{array}$ & $\begin{array}{c}\chi \\
\text { (cgs units) }\end{array}$ & $\begin{array}{c}\text { Interpretation } \\
\text { (The Formation and Type of Rocks) } \\
\end{array}$ \\
\hline 1 & $\begin{array}{l}\text { Object } 1 \\
(1.709-11.966)\end{array}$ & 0.0013 & 0.0093 & $\begin{array}{l}\text { The iron sand with alternating of silt, } \\
\text { clay, sand, and gravel from the alluvium } \\
\text { formation }\end{array}$ \\
\hline 2 & $\begin{array}{l}\text { Object } 2 \\
(1.140-30.769)\end{array}$ & -0.0029 & 0.0051 & $\begin{array}{l}\text { The rocks containing of silt, clay, sand, } \\
\text { and gravel from the alluvium formation } \\
\text { and still contains iron sand }\end{array}$ \\
\hline 3 & $\begin{array}{l}\text { Object } 3 \\
(5.128-39.886)\end{array}$ & -0.0073 & 0.0007 & $\begin{array}{l}\text { The alternating rocks of silt, clay, and } \\
\text { very fine sand from the alluvium } \\
\text { formation }\end{array}$ \\
\hline 4 & $\begin{array}{l}\text { Object } 4 \\
(30.769-92.308)\end{array}$ & -0.0006 & 0.0074 & $\begin{array}{l}\text { The alternating rocks of sandstone, } \\
\text { claystone, marl, and tuff with inserts of } \\
\text { breccia from the Halang formation }\end{array}$ \\
\hline 5 & $\begin{array}{l}\text { Object } 5 \\
(29.915-303.419)\end{array}$ & 0.0064 & 0.0144 & $\begin{array}{l}\text { Breccia with components of andesite, } \\
\text { basalt, and limestone, and insert with } \\
\text { sandstone and basalt lava from Halang } \\
\text { formation }\end{array}$ \\
\hline 6 & $\begin{array}{l}\text { Object } 6 \\
(43.590-102.564)\end{array}$ & 0.0066 & 0.0146 & $\begin{array}{l}\text { Breccia with components of andesite, } \\
\text { basalt, and limestone, and insert with } \\
\text { sandstone and basalt lava from Halang } \\
\text { formation }\end{array}$ \\
\hline 7 & $\begin{array}{l}\text { Object } 7 \\
(91,168-303,419)\end{array}$ & -0.0068 & 0.0012 & $\begin{array}{l}\text { The alternating rocks of sandstones and } \\
\text { conglomerates with claystone, marl, and } \\
\text { shale with inserts diamiktit form Halang } \\
\text { formation }\end{array}$ \\
\hline
\end{tabular}

\section{CONCLUSION}

Interpretation of the magnetic anomalies data in the Widarapayung Coast Area, District of Binangun, Regent of Cilacap has been done to identify distribution of the iron sand. The data acquisition of magnetic field intensity in this reasearch has been done in December 2015 and May 2016 using Proton Precession Magnetometer (PPM) type of GSM-19T. The research area extends on the geographic position of $109.2501^{\circ} \mathrm{E}-109.2702^{\circ} \mathrm{E}$ and $7.6781^{\circ} \mathrm{S}-$ $7.6986^{\circ} \mathrm{S}$. Then the data obtained is corrected and reducted to obtain the local magnetic anomalies data. The modelling of the local magnetic anomalies data was done using Mag2DC for Windows software version 1.59, so that be obtained several pieces of the subsurface anomalous objects.

Based on the interpretation results, the subsurface anomalous object which has a magnetic susceptibility value of $0.0093 \mathrm{cgs}$ unit and a length of $1576.7 \mathrm{~m}$ is interpreted as iron sand interspersed with silt, clay, sand, and gravel from the alluvium formation at a depth of 1.709 $-11.966 \mathrm{~m}$. The iron sand contained in this formation is estimated very prospects for economically exploitable. The other alluvium formation was also found in the research area at a depth of $1.140-30.769 \mathrm{~m}$, interpreted contain of silt, clay, sand, and gravel with a magnetic susceptibility value of $0.0051 \mathrm{cgs}$ unit. However, the content of the iron sand in the second alluvium formation is expected to be relatively small.

\section{ACKNOWLEDGEMENT}

Thanks to Rector UNSOED and Chairman of the Institute for Research and Community Service (LPPM) UNSOED upon receipt of this research project and the budget provided. Then thanks also to the Head of the Laboratory of Geophysics, Faculty of Matematic and Natural Science UNSOED on PPM and GPS equipment provided. Here after thanks to all of 
the research team consisting of lecturer and students who have worked strictly and hotly while do magnetic field data measurement in the research area.

\section{BIBLIOGRAPHY}

1 D. Z. Herman, "Kegiatan Pemantauan dan Evaluasi Konservasi Sumberdaya Mineral Daerah Kabupaten Cilacap, Provinsi Jawa Tengah”. Kolokium Hasil Lapangan (Direktorat Inventarisasi Sumberdaya Mineral, Jakarta, 2005).

2 A. Yahya, Darimana Asal Pasir Besi, GeoEducative Blog (www.andyyahya.com, 2014).

3 Kadin Bussines Center Cilacap (KBCC), Potensi Energi dan Sumberdaya Mineral, Kamar Dagang dan Industri Kabupaten Cilacap (http://kadincilacap.or.id/tentangcilacap/potensi/energi-sdm.html, 09 November 2015).

4 W.M. Telford, L.P. Geldart, R.E. Sheriff, and D.A. Keys, Applied Geophysics, (Cambridge University Press, New York, London, Melbourn, 1976), page: 105 - 114.

5 Sehah, S. A. Raharjo, dan A. Chandra, "Aplikasi Metode Magnetik untuk Mengidentifikasi Struktur Lapisan Bawah Permukaan Sungai Logawa, Desa Kediri, Kecamatan Karanglewas, Kabupaten Banyumas", Jurnal Geofisika, 14/01, 121 - 130 (2013).

6 M.E. Mostafa, "Modelling Magnetic Anomalies of Solid and Fractal Bodies with Defined Boundaries Using The Finite Cube Elements Method", Geophysical Journal International, 177/1, 62 - 70 (2008).

7 R.J. Blakely, Potential Theory in Gravity and Magnetic Applications, (Cambridge University Press, New York, 1995), page: 313 - 319, 320 - 324, 372 - 412.

8 Sehah, "Pendugaan Struktur Bawah Permukaan Gunungapi Batur Berdasarkan Data Anomali Medan Magnetik", Tesis (Program Pascasarjana, Universitas Gadjah Mada, Yogyakarta, 2001).

9 Sehah, S. A. Raharjo, dan A. Chandra, "Estimasi Kedalaman Bitumen Batubara di Desa Banjaran Kecamatan Salem Kabupaten Brebes Berdasarkan Data Anomali Magnetik", Indonesian Journal of Applied Physics (IJAP), 4/2, 171 - 182 (2014).

10 National Geophysical Data Center, Magnetic Field Calculators; Estimated Value of Magnetic Field (http://www.w3.org, 1999).

11 Asikin, Handoyo, dan Prastistho, Peta Geologi Lembar Banyumas, Jawa, (Pusat Penelitian dan Pengembangan Geologi, Bandung, 1992). 